\title{
Assessment of occupational risks in a citrus fruit extraction company in Morocco
}

\author{
Fouzia AIT EL HADJ ${ }^{1}$, Hafida RACHIDI', Fatima RACHIDI ${ }^{3,4}$ \\ 1 Continuing Education Unit - Provincial Directorate of Kenitra-Ministry of National Education, Vocational Training, and \\ Scientific Research. (PhD in Chemistry-Physics, Celle phone: 0661316119,Email : fouzia_aitelhadj@yahoo.fr) \\ 2 ENSAM RABAT, Mohammed V University (Doctor in Agroalimenataire-Management of quality and risk analysis, Cell \\ phone :0670339423, Email : rachidihafida@yahoo.fr) \\ 3 Department of Biology School Normal Superior, Mohammed V University. \\ 4 Laboratory of Biostatistics of Clinical Research and Epidemiology (LBRCE), Faculty of Medicine and \\ Pharmacy, Mohammed V University (Assistant Professor at the School Normal Superior (Doctor in Physiology and \\ Neuroscience), Cell phone:0666331032,Email :fatimarachidi1@yahoo.fr)
}

\begin{abstract}
.
The human and financial consequences of work-related accidents are major for companies and their staff. In this context, we proposed to undertake a study based on the Evaluation of Occupational Risks (EvOR) within a company processing citrus fruits into juice in its various work units. The aim of our work was to identify and prioritize the existing occupational risks and to propose preventive and corrective actions and adequate and adapted protection measures. First of all, we carried out an analysis of the work accidents that occurred in the company, and we noted an increase in the number of days off work due to work accidents, approximately 320 days per year. We then concluded that $55 \%$ of the accidents that occurred were considered to be of medium and fairly serious gravity. The method we adopted is that of the INRS and is based on five fundamental steps: inventory of work units, identification of risks, estimation of the seriousness of damage, prioritization of risks and development of a corrective and preventive action plan. The main risks identified are mainly organizational, biological, chemical, mechanical and technical. Based on the results of this analysis, we proposed a corrective and preventive action plan to the employer to eliminate or reduce the identified risks to an acceptable level, and subsequently improve the working conditions of the employees while complying with the normative and legislative texts in force.
\end{abstract}

Keywords: accidents; human profile; occupational ; Morocco

\section{I.Introduction}

Every year, millions of working days are lost due to occupational accidents and diseases. The human, financial and legal consequences of these malfunctions are major for companies and their staff, which leads to the implementation of a global prevention approach that helps and guides any employer to ensure and protect the health of its employees.

Occupational health and safety management has evolved considerably in recent years and must be integrated into the policies and strategies of all companies. It is based on general principles leading to the implementation of a prevention approach.

Citrus processing companies occupy a crucial place in the industrial sector in Morocco, and constitute an important axis of the national economic policy. As a result, the development of this sector depends mainly on the improvement of the working environment and the safety and hygiene conditions for employees. Indeed, every employer must ensure that the work premises present the hygienic and sanitary conditions necessary for the health of the workers, in addition to taking all the necessary measures to preserve the safety, health and dignity of the employees in the performance of the tasks they carry out [2].

In this sense, the Economic, Social and Environmental Council (CESE) in Morocco has undertaken to draw up a report on the subject of health and safety at work [3], emphasizing the importance of protecting and enhancing human capital, in order to enable it to benefit from the best working and production conditions and to guarantee a healthy, safe and sustainable working environment.

Since the consideration of occupational risks and accident prevention are increasingly integrated into the strategic lines of companies, social partners, governmental bodies and other actors are mobilizing to support and promote the principles of health and safety prevention in compliance with Moroccan regulations and international conventions to which Morocco is a signatory.[4]

Convinced that the health and safety of workplace personnel should not be dissociated from the functioning of the company and faced with the multiple risks inherent to activities in the industry, we carried out an assessment of occupational risks $(\mathrm{EvOR})$ in the work units within a citrus fruit 
extraction company while setting the objectives of identifying and prioritizing occupational risks and proposing adopted and adequate preventive and corrective measures.

\section{Methodology}

In this study we adopted an analytical method which consists of the evaluation of occupational risks (EvOR) in the different work units within a company processing citrus fruits into different products.

This study was carried out by a committee made up of the health, safety and environment manager and the team leaders of each work unit in five stages [5].

\section{Stage 1: Inventory of work units}

This involved taking stock of the premises by dividing them into work units and activities and observing the actual work carried out in order to identify risk situations. Similarly, a consultation with employees enabled us to collect all the data needed to draw up a descriptive diagnosis of the existing situation, based in particular on their professional experience. Indeed, the data considered useful in this study are the descriptions of the tasks performed, the instructions for using the machines, the substances handled, and the existing safety measures.

All the information required in the series of consultations with employees and team leaders at the level of each work unit is summarized in the tables below.

\section{Step 2: Risk identification}

Based on observation, this stage consists of identifying dangerous situations and recommending exposure to these dangers in relation to the tasks actually carried out at the various workstations. The aim is to detect possible sources of accidents in the workplace and to identify the people at risk.

Step 3: Estimation of potential damage:

This stage was devoted to estimating the potential damage associated with each hazardous situation and the frequency of exposure of employees to the hazards. By taking into account the different components of the actual activity, i.e. data on the operator, his task, his work equipment, his work environment, the process of occurrence of possible damage will be determined.

\section{Step 4: Prioritization of risks}

When the analysis of the risks, post by post and transversal, has been done, we then proceeded to classify these risks according to the degree of priority, this classification was carried out according to a prioritization matrix. It results from the risk rating in relation to the severity of the damage and the frequency of exposure, in order to be able to establish the priority actions, we used a matrix crossing two criteria: the severity of the damage and the frequency of the dangerous event, Figure 1[6] illustrates the rating values for each criterion

Fig 1. Prioritisation of actions matrix

\begin{tabular}{|c|c|c|c|c|c|}
\hline \multicolumn{2}{|c|}{$\begin{array}{l}\text { Frequency or } \\
\text { Probability of } \\
\text { exposure to the }\end{array}$} & $\begin{array}{l}\text { Low or } \\
\text { unlikely }\end{array}$ & $\begin{array}{l}\text { Medium } \\
\text { or } \\
\text { unlikely }\end{array}$ & $\begin{array}{l}\text { Freque } \\
\text { nt or } \\
\text { likely }\end{array}$ & $\begin{array}{l}\text { Very } \\
\text { common } \\
\text { or very } \\
\text { likely }\end{array}$ \\
\hline \multicolumn{2}{|c|}{$\begin{array}{ll} & \text { hazard } \\
\text { Severity } & \end{array}$} & $\begin{array}{l}\text { Exposur } \\
\text { e of a } \\
\text { few days } \\
\text { per year }\end{array}$ & $\begin{array}{c}\text { Exposure } \\
\text { of a few } \\
\text { days per } \\
\text { month }\end{array}$ & $\begin{array}{c}\text { Exposu } \\
\text { re of a } \\
\text { few } \\
\text { days } \\
\text { per } \\
\text { week } \\
\end{array}$ & $\begin{array}{c}\text { Daily or } \\
\text { continuo } \\
\text { us } \\
\text { exposure }\end{array}$ \\
\hline & & 1 & 2 & 3 & 4 \\
\hline $\begin{array}{l}\text { Accident or } \\
\text { illness } \\
\text { without } \\
\text { time off } \\
\text { work } \\
\end{array}$ & 1 & & & & \\
\hline $\begin{array}{l}\text { Accident or } \\
\text { illness with } \\
\text { time off } \\
\text { work }\end{array}$ & 2 & & & & \\
\hline $\begin{array}{c}\text { Accident or } \\
\text { illness with } \\
\text { partial } \\
\text { permanent } \\
\text { disability } \\
\end{array}$ & 3 & $\begin{array}{c}\text { Priority } \\
3: \\
\text { Actions } \\
\text { to be } \\
\text { planned } \\
\text { Priority }\end{array}$ & $\begin{array}{l}\text { Priority } \\
2: \\
\text { Short- } \\
\text { term } \\
\text { actions }\end{array}$ & immed & $\begin{array}{l}\text { ity } 1: \\
\text { e actions }\end{array}$ \\
\hline $\begin{array}{c}\text { Very } \\
\text { serious } \\
\text { Accident } \\
\text { or illness } \\
\text { motels }\end{array}$ & 4 & & & & \\
\hline
\end{tabular}

\section{Step 5: Drawing up the action plan}

The results of the occupational risk assessment are formalized on assessment grids and for obvious practical reasons, we have presented them in the form of summary tables grouping together the types of hazards, the main dangerous situations, the triggering events, the possible damage linked to 
these situations, and the priorities for action as well as the prevention measures adapted to each situation.

\section{Results}

Our assessment took place in a citrus fruit extraction company, which covers an area of 6 ha, of which 1.5 ha are covered, its main activity is the processing of citrus fruit and the packaging of juice and concentrated juice; the products thus manufactured are: pure juice, concentrated juice, animal feed, Flavourings, essential oils, fresh pulp, Terpene and D-limonene), most of the production is destined for export and the rest is sold on the local market.

Our occupational risk analysis study in this company covered all the processes in the factory, from the reception of raw materials to the delivery of finished products, including cleaning and maintenance.

We then divided our field of study into 24 work units listed in Table 1, each of which relates to an activity or set of activities that are dependent on each other in the manufacturing process.

Table1. Work units in the citrus extraction company

\begin{tabular}{|c|c|c|}
\hline $\mathrm{N}^{\circ}$ & Work unit & Main activity \\
\hline 1 & Réception & $\begin{array}{l}\text { Reception of raw material, weighing, unloading and storage of } \\
\text { citrus fruit }\end{array}$ \\
\hline 2 & Extraction & $\begin{array}{l}\text { Disinfection, brushing, sorting, extraction of the citrus fruit and } \\
\text { processing of the citrus fruit into juice, essential oils and pulp }\end{array}$ \\
\hline 3 & Shippoper mécanique & $\begin{array}{c}\text { Defrosting by shaking and transferring the products to the blending } \\
\text { room }\end{array}$ \\
\hline 4 & Shippoper Gulf & $\begin{array}{l}\text { Defrosting through the steam tunnel and transfer of the products to } \\
\text { the blending room }\end{array}$ \\
\hline 5 & Pastor Storck I & Pasteurization and cooling of juices \\
\hline 6 & Pasteur Storck II & Pasteurisation and cooling of juice \\
\hline 7 & Bottle line & Juice packaging in 1 litre bottles \\
\hline 8 & $\begin{array}{l}\text { Refrigeration machine } \\
\text { room }-10^{\circ} \mathrm{C}\end{array}$ & Cold production $-10^{\circ} \mathrm{C}$ for storage of semi-finished products \\
\hline 9 & $\begin{array}{l}\text { Refrigeration machine } \\
\text { room }-25^{\circ} \mathrm{C} \\
\end{array}$ & Cold production $-25^{\circ} \mathrm{C}$ for storage of semi-finished products \\
\hline 10 & Dryer & Drying of fresh citrus fruits and production of pellets (cattle feed) \\
\hline 11 & Boiler rooms & Steam production \\
\hline 12 & Aseptic filler & Packaging of concentrated juice in Bag in Box \\
\hline 13 & Finished product shop & Storage of finished products and packaging \\
\hline 14 & Tetrapack & Packaging of juice in 1 litre aseptic brik \\
\hline 15 & Mixing room & Preparation and adjustment of the product before packaging \\
\hline 16 & Mechanical workshop & Maintenance and repair of machines and installations \\
\hline 17 & Electrical workshop & Electrical maintenance of machines and light sources \\
\hline 18 & $\begin{array}{l}\text { Physical chemistry and } \\
\text { microbiology laboratory }\end{array}$ & $\begin{array}{l}\text { Physicochemical and microbiological control of the raw material up } \\
\text { to the finished product, monitoring of CIP (Cleaning in place: the } \\
\text { method of sterilisation of the machines) }\end{array}$ \\
\hline 19 & Park scrap metal & $\begin{array}{l}\text { Waste assembly, carpentry, masonry, cleaning, shovel maintenance, } \\
\text { stall tightening, scrap sorting, sewer maintenance }\end{array}$ \\
\hline 20 & Car park & $\begin{array}{c}\text { Maintenance of rolling stock, handling, driving and maintenance of } \\
\text { clark }\end{array}$ \\
\hline 21 & Refectory & A room for taking meals \\
\hline 22 & Administration & Director's office, secretariat, accounting department \\
\hline 23 & Staff cloakroom & A room for changing clothes \\
\hline 24 & Sick bay & Nurse, Health and Safety Officer and Quality Control \\
\hline
\end{tabular}

The data relating to the information collected from the operators concerning each work unit and by means of an inventory are transcribed in tables. This set of information collected specific to each work unit from the operators and team leaders allowed us to know the real work situations. Specifically in this article, we will present some models of our analysis, focusing on the main health risks involved. Table 2 shows an example of a description of the $-10^{\circ} \mathrm{C}$ refrigeration machine room 
Table 2. An example of a description of the $-10^{\circ} \mathrm{C}$ refrigeration machine room

\begin{tabular}{|c|c|c|}
\hline Work unit & \multirow{2}{*}{\multicolumn{2}{|c|}{$\begin{array}{l}\text { Refrigeration machine room } 10^{\circ} \mathrm{C} \\
\text { Cold production for storage of semi finished products (concentrated citrus juices) }\end{array}$}} \\
\hline Activity & & \\
\hline $\begin{array}{l}\text { Description } \\
\text { of the tasks } \\
\text { performed }\end{array}$ & \multicolumn{2}{|c|}{$\begin{array}{l}\text { *Mise en marche de la station en surveillant les paramètres sur tableau de commande, avec } \\
\text { enregistrement des données techniques sur un registre } \\
\text { *Contrôle des paramètres de la station : le niveau d'ammoniac, le niveau d'eau glycolée } \\
\text { *Surveillance des ventilateurs } \\
\text { *Surveillance du fonctionnement du condensateur se trouvant sur le toit de la salle :(l'opérateur } \\
\text { peut monter sur le toit } 4 \text { à } 5 \text { fois par jours) } \\
\text { *Préparation du mélange du monoéthylèneglycol } \\
\text {-le fût de l'eau glycolée est élevé par un élévateur } \\
\text {-l'opérateur met le tuyau avec robinet et prend la quantité convenable ( } 75 \% \text { de l'eau glycolée et y } \\
\text { ajoute } 25 \% \text { d'eau) } \\
\text {-l'opérateur met manuellement le mélange dans le bac de mélange liée aux réservoirs }\end{array}$} \\
\hline \multirow[t]{2}{*}{ Machinery } & machinery & $\begin{array}{l}\text { ammonia compressorsone separator } \\
\text { two evaporators } \\
\text { One condenser } \\
\text { Two monoethylglycol evaporators } \\
\text { One tank } \\
\text { Six pumps } \\
\end{array}$ \\
\hline & $\begin{array}{l}\text { Manufacturer's } \\
\text { instruction }\end{array}$ & catalogue \\
\hline \multirow{4}{*}{$\begin{array}{l}\text { Substances } \\
\text { handled }\end{array}$} & Substance & Physical form \\
\hline & $\begin{array}{l}\text { Huile pour moteurs } \\
\text { (lubtifiant) }\end{array}$ & Liquid \\
\hline & Ammoniac NH3 & Liquid and gas \\
\hline & Monoéthylèneglycol & Liquid \\
\hline \multirow{4}{*}{$\begin{array}{l}\text { Existing } \\
\text { safety } \\
\text { measures }\end{array}$} & $\begin{array}{l}\text { Personal protective } \\
\text { equipment }\end{array}$ & $\begin{array}{l}\text { Safety shoes } \\
\text { Gloves } \\
\text { Gowns }\end{array}$ \\
\hline & Signage & Not available \\
\hline & $\begin{array}{l}\text { Chemical } \\
\text { substances }\end{array}$ & No label or SDS \\
\hline & Fire extinguishers & $\begin{array}{l}1 \times 10 \mathrm{~kg} \mathrm{CO} 2 \text { fire extinguisher } \\
2 \times 6 \mathrm{~kg} \mathrm{CO} 2 \text { fire extinguishers }\end{array}$ \\
\hline
\end{tabular}

In the example of the work unit presented in the table above, the tasks carried out are described in detail, allowing us to visualize the work postures, since during the monitoring and control of the parameters of the condenser located on the roof of the room, the operator may climb onto the roof 4 to 5 times a day, which may lead to falls from a height or collisions with machines when falling.

We also focused on the prevention and safety measures in place in the company to ensure the health of its employees, individual or collective protective equipment, safety data sheets, and the existence or not of signs.

The data relating to each work situation and technique were collected and transcribed into tables of occupational risk hierarchy according to a presentation that respected the natural sequence of events, i.e. the hazards, the dangerous situations, the possible damage to health, the characterisation of the risks while taking into account the determination of the seriousness of the damage and the priority of the proposed preventive actions.

The various work units present risks qualified as a priority, particularly with regard to working at height, i.e. the scaffolding and platforms leading to the machines and large tanks are in poor condition, not forgetting the risks of fire and electrocution, the inadequacy or even absence of a safety culture with regard to work procedures and the wearing of Personal Protective Equipment (PPE), without forgetting the laxity of the rules of general and specific hygiene.

Our analysis was limited to a critical and synthetic study of the dangerous situations qualified as priorities, justifying the formulation of proposals for corrective and preventive actions capable of acting on the work situations with a view to their improvement 
Table 3 illustrates an example of an occupational risk assessment grid for the $-10^{\circ} \mathrm{C}$ refrigeration machine room. This in-depth analysis revealed factors relating to the employees and the structure itself, or both, which contribute to dysfunctions at the organizational and technical levels, and to problems of vertical and horizontal communication, without however neglecting the relational aspect.

Table 3. Occupational risk assessment grid for the $-10^{\circ} \mathrm{C}$ refrigeration machine room

\begin{tabular}{|c|c|c|c|c|c|c|c|c|}
\hline \multicolumn{9}{|c|}{ Work unit: Refrigeration machine room $10^{\circ} \mathrm{C}-\mathrm{Cold}$ production $-10^{\circ} \mathrm{C}$ for storage of semi-finished products } \\
\hline \multirow{2}{*}{ Hazards } & \multirow{2}{*}{$\begin{array}{c}\text { Dangerous } \\
\text { situations } \\
\text { Risks } \\
\text { Possible } \\
\text { damage }\end{array}$} & \multirow{2}{*}{ Risks } & \multirow{2}{*}{$\begin{array}{l}\text { Possible } \\
\text { damage }\end{array}$} & \multicolumn{2}{|c|}{$\begin{array}{c}\text { Risk } \\
\text { assessment }\end{array}$} & \multirow{2}{*}{$\begin{array}{c}\text { Priority } \\
\text { level }\end{array}$} & \multirow{2}{*}{$\begin{array}{c}\text { Existing } \\
\text { preventive } \\
\text { measures }\end{array}$} & \multirow{2}{*}{$\begin{array}{l}\text { Proposed } \\
\text { preventive } \\
\text { measures }\end{array}$} \\
\hline & & & & $\mathrm{S}$ & $\mathrm{F}$ & & & \\
\hline \multirow{2}{*}{$\begin{array}{l}\text { Ammonia } \\
\text { leakage at the } \\
\text { compressors }\end{array}$} & $\begin{array}{l}\text {-Inhalation } \\
\text {-Skin } \\
\text { splashes }\end{array}$ & $\begin{array}{l}\text { Health } \\
\text { risk }\end{array}$ & $\begin{array}{l}\text {-Asphyxie } \\
\text {-Corrosion } \\
\text { cutané } \\
\text {-Lésions } \\
\text { oculaires } \\
\text { grave } \\
\end{array}$ & 3 & 3 & 1 & no exist & $\begin{array}{c}\text {-Provide a } \\
\text { protective mask } \\
\text { with an } \\
\text { ammonia filter }\end{array}$ \\
\hline & $\begin{array}{c}- \\
\text { Environment } \\
\text { al pollution }\end{array}$ & $\underset{\text { risk }}{\text { Climate }}$ & $\begin{array}{l}\text { Toxicité de } \\
\text { l'environn } \\
\text { ement }\end{array}$ & 2 & 2 & 2 & no exist & $\begin{array}{l}\text {-Check and } \\
\text { maintain } \\
\text { ammonia lines } \\
\text { periodically }\end{array}$ \\
\hline $\begin{array}{l}\text { The floor of } \\
\text { the room is } \\
\text { defective }\end{array}$ & $\begin{array}{l}\text { Falling or } \\
\text { slipping on } \\
\text { the same } \\
\text { level }\end{array}$ & $\begin{array}{l}\text { Health } \\
\text { risk }\end{array}$ & $\begin{array}{c}\text {-Entorses } \\
\text { - Fractures } \\
\text {-foulures }\end{array}$ & 3 & 4 & 1 & $\begin{array}{c}\text { Existence } \\
\text { des } \\
\text { chaussures } \\
\text { de sécurité } \\
\text { mais ils } \\
\text { sont usées }\end{array}$ & $\begin{array}{l}\text { Maintain the } \\
\text { floor well } \\
\text {-Change safety } \\
\text { shoes } \\
\text { periodically }\end{array}$ \\
\hline $\begin{array}{l}\text { Stairs to the } \\
\text { condenser are } \\
\text { not protected }\end{array}$ & $\begin{array}{c}\text { Fall from } \\
\text { height }\end{array}$ & $\begin{array}{l}\text { Health } \\
\text { risk }\end{array}$ & $\begin{array}{c}\text {-Entorses } \\
\text {-Fractures } \\
\text {-foulures }\end{array}$ & 3 & 4 & 1 & no exist & $\begin{array}{c}\text {--Installing a } \\
\text { guardrail }\end{array}$ \\
\hline $\begin{array}{l}\text { Open cable at } \\
\text { the } \\
\text { compressor }\end{array}$ & $\begin{array}{l}\text { Electrocutio } \\
\mathrm{n} \text { shock }\end{array}$ & $\begin{array}{l}\text { health } \\
\text { risk }\end{array}$ & $\begin{array}{l}\text {-Incendie } \\
- \\
\text { électrocuti } \\
\text { on }\end{array}$ & 3 & 4 & 1 & $\begin{array}{l}\text { Existence } \\
\text { des } \\
\text { extincteurs }\end{array}$ & $\begin{array}{l}\text {-Provide gloves } \\
\text {-Periodically } \\
\text { check the cables } \\
\text { of the machines }\end{array}$ \\
\hline $\begin{array}{l}\text { Cold level - } \\
\text { 10C }\end{array}$ & $\begin{array}{l}\text { Increased } \\
\text { fatigue, loss } \\
\text { of dexterity }\end{array}$ & $\begin{array}{l}\text { health } \\
\text { risk }\end{array}$ & $\begin{array}{l}\text { Hypotherm } \\
\text { ie } \\
\text { Troubles } \\
\text { musculo- } \\
\text { squelettiqu } \\
\text { es }\end{array}$ & 2 & 2 & 2 & no exist & $\begin{array}{l}\text {-Limit the time } \\
\text { spent working } \\
\text { in cold rooms } \\
\text {-Provide PPE } \\
\text { adapted to the } \\
\text { existing cold } \\
\text { level }\end{array}$ \\
\hline
\end{tabular}

\section{Discussion}

Our study has revealed several shortcomings and failures relating to the operation of the various work units, and to an underestimation of the risks, either through negligence, lack of information or lack of awareness of the existence of the risks. Thanks to the observation of work situations, and based on interviews with operators, who are in the best position to express themselves on the risks of their work situations, we succeeded in identifying the dangers by analyzing the real activity of the 
operators, starting from what exists to understand the emergence of risks.

We devoted part of our work to the analysis of work accidents over a given period, which showed an increase in the number of days off work of about 320 days per year, and about $55 \%$ of the accidents that occurred were considered to be of medium and fairly serious degree. Although the statistics of work accidents related to given work situations are important indicators for identifying hazards, we were very interested in the observation of the work environment, tools and machines. The main risks were mainly organizational, mechanical and technical without neglecting the electrical and psychosocial risks.

Most of the health risks observed in our study were mechanical, with falls from height and slips constituting the majority of accidents occurring in high frequency work units. For falls from height, the exercise of the tasks assigned to the operators requires them to move on roofs, frames, the terraces of TetraPacks, and other large tanks, ladders, stairs, walkways and scaffolding, which are not in good condition and which lead to falls from height, and sometimes the operator during the fall can hit a machine or tools that have fallen to the ground [7 ]. To remedy this, we have proposed as preventive actions, the installation of guardrails at the level of gangways or to maintain them if they exist, which constitute collective protection equipment. Similarly, the repair of ladders and scaffolding that have already deteriorated due to corrosion is an essential action to prevent risks, as the employer is obliged to ensure the daily control and proper maintenance of fall protection elements, according to international requirements [8].

In view of the nature of the activity in the company, the falls of full feet related to slips are also constituted a critical risk in our analysis [9 ] in fact, we noted the presence of liquids either of the juices or of water on the ground, or other substances entering in the operation of the machines, without forgetting the state of the defective ground, which leads to falls of full feet entraining damages of level of gravity 3 . In this sense, among the actions to be carried out, we proposed to proceed to a repair of the floor, to eliminate the products on the floor by installing slight slopes for the evacuation of water which will have to be directed towards gutters and pits covered with wire mesh.

On the other hand, we have noticed a lack of hygiene and cleanliness in the workplaces, which is why we have proposed actions aimed at maintaining good order and cleanliness in the workplaces, by clearing the gangways of cumbersome objects.

We have also noticed the presence of cables in the open air, which leads to risks of elocution and fire in some work units.

We also detected dangerous situations caused by leaks of substances with which the machines operate, notably ammonia in the refrigeration machine room and nitrogen in the pasteurization unit, so the adoption of preventive measures is very interesting, such as the wearing of PPE and the periodic inspection of machines.

The biological and chemical risk is present with less frequency in the physic-chemical and microbiological analysis laboratory, in which case we proposed actions to remedy it, such as wearing adequate protective equipment and checking its condition daily. 10] We noted other risks related to the work environment, such as working in high heat, in particular due to the release of steam, or the presence of high-temperature nitrogen pipes in the boiler room, the pasteurization room and the mixing room. This risk can lead to discomfort, lack of alertness, severe burns, profuse sweating, nausea and headaches. Faced with this risk, the most effective prevention consists in avoiding or at least limiting exposure to heat. [11. To do this, it is possible to act on the organization of work (increase in the frequency of breaks, rotation of tasks, layout of premises, in particular providing air-conditioned rest areas, ensuring that hot air is evacuated by general or localized extraction, installing a ventilation and hot air extraction system and eliminating vapor leaks (Table 4). 
Table 4. An example of a heat-related risk assessment

\begin{tabular}{|c|c|c|c|c|c|c|c|c|}
\hline \multirow{2}{*}{ Hazards } & \multirow{2}{*}{$\begin{array}{l}\text { Dangerous } \\
\text { situations } \\
\text { Risks } \\
\text { Possible } \\
\text { damage } \\
\end{array}$} & \multirow{2}{*}{ Risks } & \multirow{2}{*}{$\begin{array}{l}\text { Possible } \\
\text { damage }\end{array}$} & \multicolumn{2}{|c|}{$\begin{array}{c}\text { Risk } \\
\text { assessment }\end{array}$} & \multirow{2}{*}{$\begin{array}{l}\text { Priority } \\
\text { level }\end{array}$} & \multirow{2}{*}{$\begin{array}{l}\text { Existing } \\
\text { preventive } \\
\text { measures }\end{array}$} & \multirow{2}{*}{$\begin{array}{c}\text { Proposed preventive } \\
\text { measures }\end{array}$} \\
\hline & & & & S & $\mathrm{F}$ & & & \\
\hline $\begin{array}{l}\text { Dégagement } \\
\text { de vapeur } \\
\text { Vapor release }\end{array}$ & $\begin{array}{c}\text { Hot } \\
\text { environment }\end{array}$ & health risk & $\begin{array}{l}\text { Discomfort } \\
\text { Lack of } \\
\text { alertness } \\
\text { Burning }\end{array}$ & 3 & 3 & 1 & No exists & $\begin{array}{c}\text {-Install a ventilation } \\
\text { system } \\
\text {-Eliminate steam } \\
\text { leaks } \\
\text {-increase the } \\
\text { frequency of breaks }\end{array}$ \\
\hline $\begin{array}{c}\text { High } \\
\text { temperature } \\
\text { nitrogen line }\end{array}$ & $\begin{array}{l}\text { Working in } \\
\text { a heat }\end{array}$ & health risk & Burns & 3 & 3 & 1 & $\begin{array}{c}\text { Gloves exist } \\
\text { but are not } \\
\text { suitable }\end{array}$ & $\begin{array}{l}\text {-Provide PPE } \\
\text { appropriate to the } \\
\text { work situation }\end{array}$ \\
\hline
\end{tabular}

Similarly, working in the cold in the two refrigeration machine rooms constituted a major risk which has effects on the health of employees, particularly hypothermia and musculoskeletal disorders. The most effective measures consist of avoiding or limiting the time spent working in the cold, and providing suitable work equipment [12].

Without neglecting, however, that we have observed in almost all work units the noise nuisance and that we have not been able to measure it due to lack of measuring equipment, these noise nuisances cause multiple effects on health such as hearing fatigue, deafness [ 13 ], in general, a measurement of the noise levels to which workers are exposed, has the purpose of determining mainly the level of daily noise exposure and to decide on appropriate prevention measures.

This measure makes it possible to inform employees of certain risks specific to certain objects, activities or situations. It may take the form of a sign, a color, a light or an acoustic signal [14]. In our case, we found that signage in almost all the work areas is absent, whereas in the bottle line unit and the Tetrapack unit, signage exists but is not adapted to the nature of the tasks performed. Also, in the physicochemical and microbiological analysis laboratory, we note the existence of signage but in an incomplete way without neglecting the absence of safety data sheets, these documents are essential in the construction of a professional risk assessment approach, in fact The safety data sheet is used to identify the dangers when handling a chemical product by providing us with the effects on human health and the environment on the one hand and useful information for using it safely on the other.[15]
All these preventive measures can only be applied by the personnel concerned after they have acquired a better knowledge of the risks to which they are exposed, and this knowledge requires training and information for these employees regarding the importance of collective and individual preventive measures, the handling of substances, and the use of machines. Indeed, all operators should be informed of the hazards associated with the performance of the tasks assigned to them, how to obtain and use the information provided by labels and safety data sheets. Furthermore, it is recommended that training and awareness-raising sessions be conducted for employees on the correct and effective way to apply safety measures, especially technical and individual prevention measures, and also on what to do in case of emergency.

\section{V.Conclusion}

The activities in the food industry sector generate several risks, essentially the risk linked to organisational and technical constraints, and is considered a high-risk work environment due to the handling of large machines and various substances. And then to inaugurate a health and safety management system [16].

Thus, it appears necessary to improve prevention by understanding the exposure to risks and dangers through an assessment of occupational risks in each work unit in the company, which makes it possible to preserve the safety and health of people, This priority approach of any company must be updated regularly and whenever useful.

The prevention of occupational risks is the priority approach of any company in order to improve working conditions, and involves taking the necessary measures to preserve the safety of 
workers and machines. These measures are the result of significant choices and priorities.

In order to achieve the objectives in the face of avoidable risks, it is important to implement a strategy likely to act on the behaviour of the personnel in order to develop a safe and preventive culture among them. Moreover, our contribution to the actions to be carried out to control or eliminate the risks is translated in the form of a preventive action plan, which constitutes the heart of the risk management within the company.

\section{References}

1. Occupational risk assessment - Help in identifying risks in SMEs, INRS, edition 840, November 2018

2. Moroccan Labour Code, consolidated version dated 26 October 2011 and Moroccan Labour Code, 2021 edition, article 24, article 281 and 282

3. Occupational Health and Safety: Essential Support for Economic and Social Development, 116th Ordinary Session, 26 November 2020

4. Practical guide to health and safety at work, CGEM, September 2017)

5. 5BROCHURE: Step by step towards RISK ASSESSMENT AND

MANAGEMENT, ACCIDENT INSURANCE ASSOCIATION, 21/03/2018

6. Guide to assessing work risks, SISTRA, August 2017

7. Sophie ANDRÉ, Alain PAMIES, Patrick LAINE, Prevention of occupational risks Risks of falling from height, September 2015

8. Risks related to falls from height, INRS, 2021

9. Falls from the ground, INRS, 2018

10. Personal protective equipment (PPE) Rules for use, ED 6077, October 2013.

11. Work in heat, INRS, 2021

12. Working in the cold, INRS, 2020

13. Noise pollution, Dossier Work and safety, May 2019

14. Occupational health and safety signsregulation, INR, July 2017

15. the safety data sheet, Edition 954, INRS, June 2019

16. the safety data sheet, Edition 954, June 2019
17. Occupational health and safety management system-Guide, NM 00.5.800, [17 ] Occupational health and safety management system-Guide 00.5801 